\title{
Paraguay: a housing finance proposal for middle- to low-income groups
}

\author{
J. Vicente Fruet Cardozo and Guzmán A. Muñoz Fernández
}

ABSTRACT

The construction and ownership of homes is fundamental to economic development, the generation of wealth and the formation of the middle class. Although a number of studies have been conducted and programmes implemented in recent decades, there remains a significant housing deficit in Paraguay and Latin America, indicating that such programmes have been unsuccessful. For families unable to document a steady income, the main obstacle to homeownership is often financing. This paper aims to demonstrate the economic and financial feasibility -provided there is sufficient political will and coordination between public and private entities - of a project to build 75,000 homes for 300,000 people (4.5\% of the Paraguayan population) with middle to low incomes. The median household income in this segment, for which there is a significant shortage of decent housing, is US\$ 396.50. A maximum of US\$ 63.44 per month may be set aside for housing costs. at the University of Cordoba, Spain. es1frcaj@uco.es

Guzmán A. Muñoz Fernández is a professor in the Department of Statistics, Econometrics, Operational Research, Business Management and Applied Economics at the University of Cordoba, Spain. guzman.munoz@uco.es 


\section{I}

\section{Introduction}

Housing is the most important family asset and a basic human need. As essential as food and livelihoods, it has been regarded as a basic indicator of a country's economic situation. It is probably one of the main social sectors targeted by legislators and public policymakers, who act on the basis that housing is a basic right enshrined in the legislation of leading countries. This right is found in three different articles of Paraguay's Constitution, according to which the State must promote social housing plans aimed at low-income families through the provision of adequate financing. Yet many citizens live in substandard housing, and some families cannot even afford basic housing. Others have the income to purchase a better house but cannot obtain a mortgage, whether because they are unable to properly document their income, because credit markets are very shallow, or simply because the mortgage is too expensive. In other cases, there are no houses for them to buy (Bouillon, 2012).

The main challenges faced by Paraguay's housing sector are to eliminate those quantitative and qualitative deficits and to meet the need for the construction of new homes. According to the National Fund for Social Housing (FONAVIS), most of the housing programmes implemented by government agencies such as the former Paraguayan Institute of Housing and City Planning (IPVU), the former National Housing Bank and the former National Housing Council (CONAVI) have been directed at socioeconomic strata with an actual payment capacity, attending only sporadically to the needs of low- or no-income families. Most of these programmes have failed since they went into arrears due to non-payment shortly after, resulting in significant social problems. All this was principally caused by political inaction, corruption or both, and given the distrust that surrounds the misuse of funds, the administration responded by not allocating funds or not fully exploiting the budgeted resources. ${ }^{1}$ Another significant problem is that housing programmes are unsustainable, both those financed by the government and those financed by non-governmental organizations and foreign institutions.

\footnotetext{
1 According to the Integrated Budget Programming System and the Integrated Accounting System (SIPP-SICO), which form part of the Integrated Financial Administration System (SIAF), only $63 \%$ of the budgeted 616 billion guaraníes (US\$ 135.52 million) was executed in 2012 .
}

The urban population accounts for $59.53 \%$ of Paraguay's population, and $43 \%$ of the country's population lives in metropolitan areas of Asunción, which is made up of 20 municipalities (Páez, 2011). Nevertheless, most people live in a detached house or "casa" (83.92\%), followed by a hut or "rancho" (11.54\%) according to the Department of Statistics, Surveys and Censuses (DGEEC). These two types of dwelling represent $95.46 \%$ of the total housing stock. The predominance of these dwellings has been slowly declining over the last 30 years; however, their prevalence suggests that the land has been urbanized horizontally rather than vertically in Paraguay, reflecting, among other factors, the available options for occupying the existing physical space. There are also a large number of consolidated developing suburbs, which are filled, not with houses to live in, but with bare residential plots interspersed with built-up plots. This occurs even in non-central city areas.

This paper puts forward a financing plan that offers a housing solution for 300,000 Paraguayan citizens. It would help address the deficit and specifically focuses on middle- to low-income families with no access to the housing finance market. Without a doubt, large projects such as this can act as an economic driver, boosting the country's domestic consumption. They can also make financing available for new economic activities and offer mortgage security tools to many citizens. This proposal is not based on building urban housing estates in the Western sense, whereby a developer builds the houses, the infrastructure and the new services for the houses, which then drives up the house prices, meaning that a large up-front investment is needed. Rather, the emphasis is on self-building and building by small-scale construction companies so as to take advantage of the small plots owned by many Paraguayan families. These are middle- to low-income families who do not have the capacity to fund the construction of decent dwellings, so the proposal outlined below focuses mainly on what is known in the FONAVIS housing programme rules as "building on own plot."

For the project to be successful, the authorities would need to take action on two fronts: (i) from a technical perspective, the design must meet the minimum FONAVIS technical and structural requirements, and progress must be made on the development of district civil works; 
and (ii) the building work should be financed through periodic payments against units of work duly performed and checked. The objective is an annual tendering of 7,500 houses up to $60 \mathrm{~m}^{2}$ in size; their construction should be started each year, but will be completed over a longer period, with the final payment made on project completion.

This paper analyses the financial viability of meeting this objective. Section II contains a review of the economic literature on housing finance. In section III, we calculate Paraguay's housing deficit, in order to determine the parameters of the population segment under consideration. Section IV sets out the proposed financing and amortization plan for the construction of the homes, and details the economic operators whose involvement would be required. Finally, conclusions and recommendations for housing policy are presented in section $\mathrm{V}$.

\section{II}

\section{Housing financing and literature review}

Household incomes are cited in the classical economic literature as one of the main factors that determine the demand for housing (Norton, 1955; Friedman, 1957; De Leeuw, 1971; and Poterba, 1984, among others). Households consume housing services subject to the limitations imposed by their income and the cost of housing; this logical approach was proposed by Muth (1969) who also put forward the "permanent income" hypothesis. An assured or expected household income will, over a long period of time, encourage families to spend on and invest in durable goods, including houses, which will in turn increase the demand for regular housing. First though, a distinction must be made between buying capacity and payment capacity. The former refers to the connection between house prices and the average wage, depends on the family's disposable income, and is closely linked to the average household income and to stable jobs. Payment capacity relates to the strain payments exert on disposable income, and is associated with the following credit conditions: financing availability, financing rate on house appraisal, the attitude of property developers, and the entities in charge of arrears and repayment terms, which will determine the share to be paid by each household. Other key factors are access to loans, the loan terms, and how these resources are subsidized (Fallis and Smith, 1984; Muellbauer and Murphy, 1997; Young, 2007).

Mortgage loans require long-term monthly payments, a demonstrable credit history, and a stable and verifiable source of income - in other words, paid employment in the formal sector. Many households in developing countries on low or middle incomes have fluctuating and often informal sources of income. Very few have any kind of credit record and many have no legal title to their landholdings. Therefore, property rights and the ability to recover after foreclosures are some of the main problems of traditional mortgage financing. Private financial institutions accordingly have little interest in expanding their mortgage financing plans to this market (Daphnis, 2006). Another significant impediment to the development of the Latin American mortgage market has been the abuse of institutional "no collection" practices, owing to a lack of guidelines on financial recovery in the housing policies run by various agencies. This, for political reasons, has in most cases led to a rise in the "non-payment" culture (Connolly, 1997).

Homeownership is fundamental to countries' economic development and is especially important in the generation of household wealth and the creation of a middle class (Ferguson and Navarrete, 2003). De Soto (2000) discusses the implications of property rights institutions for economic development. His hypothesis is that secure property rights increase long-term capital accumulation and access to credit, leading to economic growth. Bauer (2000) also argues that capital formation is essential for an economy to progress from subsistence production to market production. Other authors provide theoretical links between the security of property rights and economic development (Acemoglu, Johnson and Robinson, 2002; Kerekes and Williamson, 2008). An appropriate property rights framework helps in turn to strengthen the financial system, because it is a more secure way of issuing private debt and the risks associated with mortgage lending are low. Real estate lending represents over one third of total bank loans in developed countries. By contrast, developing countries have a shortage 
of housing assets, which impacts negatively on their financial systems. Banks that are unable to invest in mortgage lending have to invest a larger proportion of their funds in riskier projects. A dwelling is not just a shelter; it is also a product that provides social security, because it can function as a space for income-generating activities, such as a shop or a workshop that combines shelter with production, and as collateral in the event of financial need (Smets, 2006). Growth of the domestic market also helps to provide an alternative for economies that depend on exports (Ferguson, 2006), especially of raw materials.

Compared to developed countries, where homeownership comes down to renting or buying, most developing nations have an informal housing market consisting of one or more of the following: irregular, self-construction housing projects (either on one's own land or on illegally occupied land), sublet housing divisions, and shared accommodation (Coccato, 1996). The main reason why households cannot afford a formal property is lack of income. In Latin America, this is compounded by poorly functioning financial markets, the difficulty of providing reliable income information, and the tight supply of social housing offered by the private sector.

With no access to financing, poor households are limited to buying small quantities of building materials and constructing inferior quality homes. This is a case where microcredit can be used to foster social development and combat poverty. Short-term loans at unsubsidized interest rates (Serageldin and Driscoll, 2000) of between US\$ 500 and US\$2,000 (Ferguson and Smets, 2010) can be used to buy materials for informally built housing, the ultimate objective of which is to extend and improve the owner's home (incremental housing). The soundness of the loans, which are channelled through non-governmental organizations, is based on ongoing supervision rather than on real guarantees. The aim is to apply financial resources for housing to the informal house-building sector (González Arrieta, 2005).

However, some literature suggests that microcredit can be used not only to improve homes, but also to provide opportunities for the construction of new, basic housing units. For Hammond and others (2008), many loan applications are submitted for between US\$ 2,500 and US\$10,000, which correspond to lower- and middle-income families, who also lack access to financial services. This impressive potential market could generate as much as US\$ 331.8 billion worldwide. Traditional mortgage institutions have not devised mechanisms to serve these markets, nor have institutional bodies offered microcredit or larger loans to buy or improve houses. To satisfy this demand, longer 10-to-30-year loans are needed, along with lower interest rates, new methods (including for funding and servicing loans, and risk management) and institutional innovation (Ferguson and Smets, 2010). A wide range of innovative credit products must therefore be designed in order to meet housing needs in developing countries such as Paraguay.

\section{III}

\section{The housing sector in Paraguay}

According to the 2012 annual report published by the National Secretariat for Housing and Habitat (SENAVITAT) and the Department of Statistics, Surveys and Censuses (DGEEC), Paraguay's housing deficit stood at 1.2 million homes on 31 December of that year. This total can be broken down as follows: 150,000 houses to be constructed, 300,000 houses in need of major repairs (these two categories may be considered as urgent problems), 320,000 houses to be extended, and another 430,000 which are not a priority. Paraguay has 6,600,000 inhabitants and 1,652,895 houses (so, an average of four people per house). This means that $3,080,000$ people ( $46.7 \%$ of the total population) have urgent housing problems. The proposal set out in this paper focuses on the construction of 75,000 houses over a period of 10 years (one half of the "to be constructed" segment of figure 1). This represents a target of 300,000 beneficiaries, of the 377,244 found in table 1 , decile 5 . These families must own land equivalent in value to around US\$1,600, which will form the counterpart contribution.

The unit cost of this kind of house is estimated at US $\$ 8,000$, on the basis of the unit cost of 38 social houses that were handed over to their new owners by 
FIGURE 1

Distribution of housing deficit, 2012 (Number of houses)

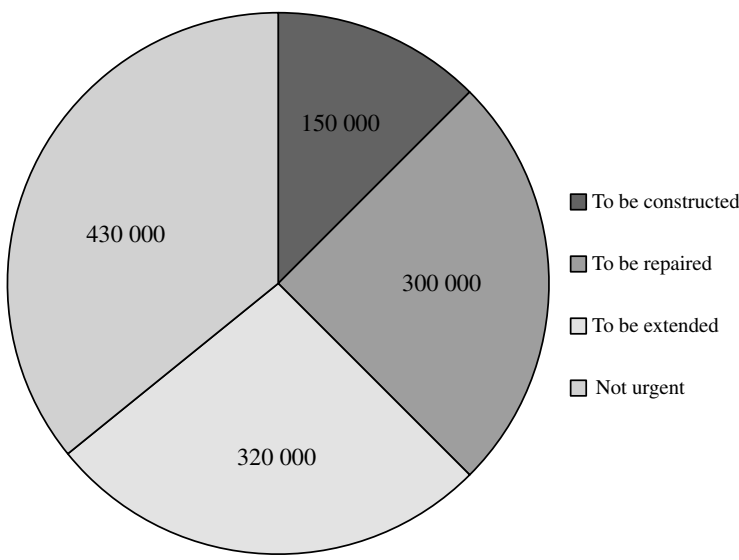

Source: Prepared by the authors, on the basis of Department of Statistics, Surveys and Censuses, Permanent Household Survey, 2012 [online] http://www.dgeec.gov.py/Publicaciones/Biblioteca/ EPH2012/principales_resultados_EPH2012.pdf.

SENAVITAT in July 2012. The total investment needed to solve this social problem would therefore be around US\$ 9.6 million. This is undoubtedly a huge sum for the weak Paraguayan economy.

The government plays a very limited role in this sector. The State manages some social housing programmes, and builds around 5,000 homes a year, but the actual demand is around 15 to 20 times greater than this, according to a statement made by Francisco Knapps, former SENAVITAT president, in October 2013. This therefore only establishes a reasonable framework for regulating the parameters of an acceptable housing project and the places where homes could be built. Official figures confirm that $96.92 \%$ of the houses built in Paraguay from 1950 to 2010 were constructed by the private sector.

For this reason, it is clear that unless the Paraguayan government, in conjunction with the private sector, intervenes in the housing sector, the market will never be able to offer a real solution to this alarming situation. In that respect, the government should take action on three levels: (i) the formulation of a housing policy in Paraguay; (ii) a commitment from the Development Finance Agency (AFD) ${ }^{2}$ in conjunction with sEnAVITAT,

\footnotetext{
${ }^{2}$ On 27 July 2005, the date Act 2640 was promulgated, the Development Finance Agency (AFD) was created as the sole second-tier public bank. It has replaced several public banks, among them Banco Nacional de Ahorro y Préstamo para la Vivienda (BNAPV).
}

the main housing agency in Paraguay to participate; and (iii) the acquisition of easy financial resources to finance a building programme for this number of people.

\section{Housing deficit and the population affected}

This study focuses on the specific segment of the population found in the fifth line of table 1 , which illustrates how disposable per capita income was distributed in 2012 (DGEEC, 2012). The results of the table lead to the so-called Lorenz curve, which is a graphical representation of the cumulative distribution function of the empirical probability distribution of wealth. We have divided Paraguay's poor population into five groups, according to the distribution of disposable per capita income. Per capita income in Paraguay, based on purchasing power parity (PPP) and expressed in 2012 PPP dollars, is $\$ 4,545$. In table 1 , it has been disaggregated into deciles.

\section{Classification of the population affected}

The population group shown in line 5 of table 1 , which we have called "middle- to low-income," represents families that earn the minimum wage (around US\$396.50 per month). They do not have access to bank financing due to the high cost of mortgage loans. In order to simplify our calculations, we have rounded the number of people in this group down from 377,244 to 300,000 , who are therefore in need of approximately 75,000 houses.

\section{What about the first four deciles?}

The other four groups, found in lines 1 to 4 , which we have designated as "very low income," represent about $11.32 \%$ of the total population, or around 747,320 people. They live in the poor outlying areas of the cities and are among the population living under the poverty line. ${ }^{3}$ This means that they do not have even the US\$ 2 needed to buy enough food every day. They have no borrowing capacity owing to their low level of income, and therefore a mortgage programme to finance the 186,830 houses they need would not be viable. Housing programmes for these groups are generally run and funded by foreign agencies or international charities.

\footnotetext{
3 See UNDP (2010). This report places $29.8 \%$ of the Paraguayan population under the poverty line.
} 


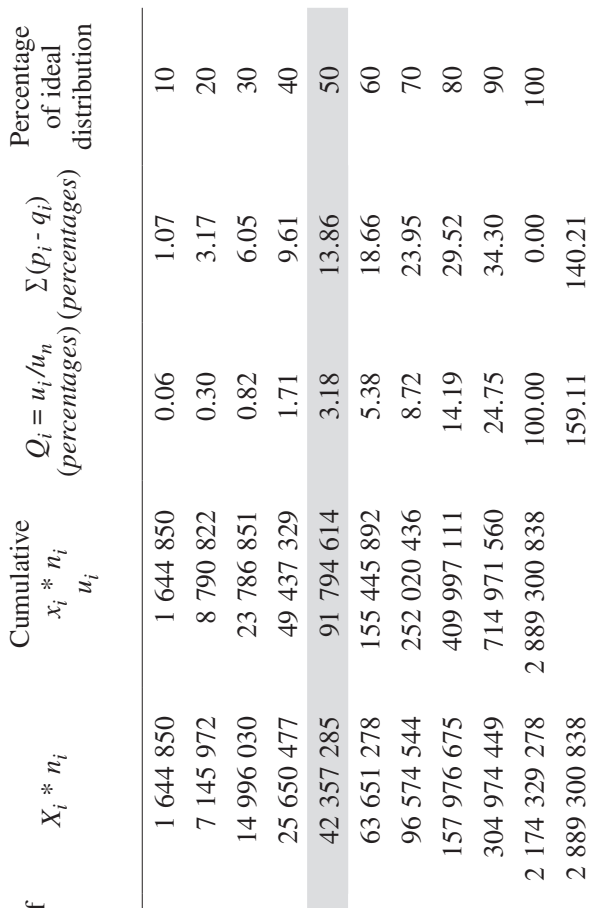

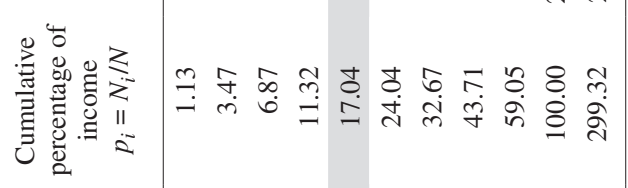

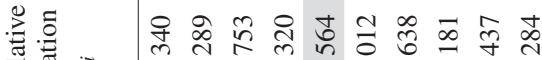

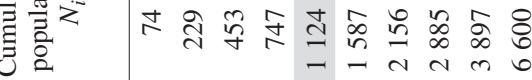

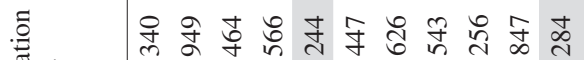
告 4

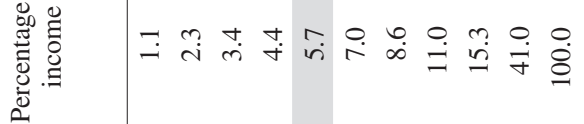

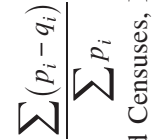

密弯

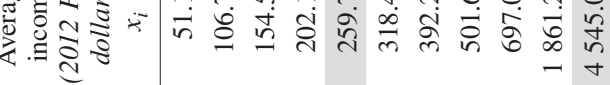

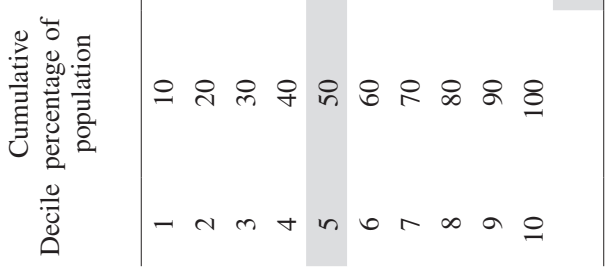

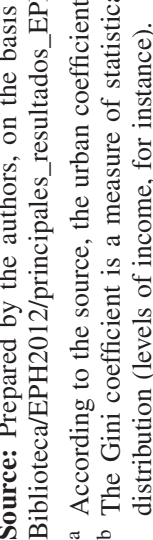




\section{IV}

\section{Financing options for the housing sector}

\section{Financing option for the middle- to low- income group}

\section{(a) General concepts}

We have developed a housing financing project for this group that involves a 20-year credit line, appropriate terms for their disposable per capita income, and a grace period of four years. The loan would be issued through the Development Finance Agency (AFD), which would act as a second-tier bank. ${ }^{4} \mathrm{~A}$ total of 12 first-tier entities (intermediary financial institutions) would participate in this proposal: 11 loan cooperatives that are already participating in other AFD programmes, and one savings and loan association. The cooperatives are: Lambaré, Mburicaó, Medalla Milagrosa, Copacons, Coomecipar, Universitaria, Educadores, San Juan Bautista, Ayacapé, Ypacaraí and Fuerzas Armadas de la Nación. The savings and loan association is Solar de Ahorro y Préstamo para la Vivienda. Commercial banks have not been considered

\footnotetext{
${ }^{4}$ A second-tier financial institution does not grant loans to borrowers directly, but rather operates through first-tier institutions such as commercial banks, mortgage banks, savings and loan associations, and loan cooperatives.
}

for two reasons: first, because middle- to low-income groups tend not to approach these kinds of institutions; and second, because commercial banks will participate in the project's secondary market.

\section{(b) Amortization table of the loans issued by AFD to first-tier entities}

Table 2 presents the financing granted by AFD to the first-tier entities in more detail. It is important to note that the AFD policy for financing social housing stipulates the use of fixed interest rates for a maximum of 20 years. Specifically, the entity recommends an annual interest rate of $5.5 \%$ for loans to beneficiaries earning up to five times the minimum wage. To this percentage, the intermediary financial institutions can add a maximum of $4 \%$; in other words, the maximum annual interest rate is $9.5 \%$, which results in an annual effective interest rate of $7.25 \%$.

\section{(c) Amortization table for each family's mortgage}

Presented below is the table corresponding to the mortgage for middle- to low-income families with four members. This scenario assumes that the mortgage is paid by only one person, which is a positive aspect of the project, since often more than one person works in

TABLE 2

General data regarding the loans issued by AFD to first-tier entities

Number of houses

Individual cost of each house

US\$ 8000

Total project investment

US\$ 600000000

Total financing by AFD through first-tier entities

Annual project investment 
a middle- to low-income family. Also, as mentioned in section III, programme beneficiaries must possess a landholding worth around US\$1,600, which will form the counterpart contribution. In this sector, average household incomes correspond to the minimum wage of US\$ 396.50 . We estimate that up to $16 \%$ of this figure can be set aside for payment of a minimum and decent level of housing - around US\$ 63.44 per month, or US\$ 761.28 a year- . Beneficiaries may use up to $16 \%$ of the minimum wage to service their mortgage debt. This percentage represents the cost of a basic monthly food basket for one person. Given that each household is, on average, made up of four members, the four members should be able to subsist on a basic basket for three. The upside would be the possibility of owning a home. If they had to pay more than $16 \%$, the project would not be feasible (DGEEC, 2011a). The other figures are presented in table 3.

TABLE 3

General data regarding the loans granted by first-tier entities to middle- to low-income beneficiaries

\begin{tabular}{|c|c|c|}
\hline Number of houses & & 75000 \\
\hline Unit cost of each house & & US\$ 8000 \\
\hline Financing of AFD through first-tier entities & $80 \%$ & US\$ 6400 \\
\hline Beneficiaries' contribution & $20 \%$ & US\$ 1600 \\
\hline Deadline for repayment & & 20 years \\
\hline Total interest & & US\$ 10800 \\
\hline Fixed interest rate of the loan granted by the first-tier entity & & $9.5 \%$ \\
\hline Effective interest rate & & $11.69 \%$ \\
\hline General and administrative costs & & $5.0 \% \mathrm{~b}$ \\
\hline Grace period for principal repayment & & 4 years \\
\hline Payment method & & Quarterly \\
\hline Number of years to build the houses & & First 10 years \\
\hline
\end{tabular}

Source: Prepared by the authors.

a For social projects of this nature, which are aimed at people on middle to low incomes, fixed interest rates are recommended. The loans are granted to first-tier financial institutions by AFD at $5.5 \%$. The latter lend to beneficiaries at $9.5 \%$.

b This is collected on interest received.

The annual repayment table for each family is shown in annex 1. The last column shows the total amount to be paid annually by families in the middle- to lowincome group. In years 5 to 10 , the annual sum to be paid by households slightly exceeds their capacity to pay, calculated as US\$ 761.28. However, this situation should resolve itself since the minimum wage rises every year.

\section{(d) Cash flow of the housing financing project}

The cash flow of a project is an economic and financial statement that summarizes the cost-benefit analysis carried out. The main aim is to prove the viability of the project, which means that the addition of future flows updated at a discount rate must be superior to the initial investment. The best component for defining viability is the net present value (NPV). In this kind of business venture in the private sector, the matter is simpler: the NPV must be positive and the businessman or woman must be happy with it. For social projects, the matter becomes more complex. Another component in the analysis is the internal rate of return (IRR). This is less important than the NPV and determines the break-even point of the project.

With regard to cash flow, the following points should be considered:

- The project profile was prepared from the AFD point of view.

- The houses will be constructed over a period of 10 years; from years 0 to 9 , an estimated 7,500 houses will be built a year.

- During those 10 years, AFD, through the first-tier entities, will provide mortgages for construction in 10 equal amounts. This represents the initial project investment.

- Although the loan repayment table covers a 20-year period, the project's life cycle is 29 years. This is because the loans for the construction of the last group of 7,500 houses are issued in year 9, but there is a grace period of four years in which to start principal repayments, meaning the capital 
repayment of the loans granted in year 9 begins in year 13. Beneficiaries then have another 16 years to pay off the loans. This is the reason it finalizes in year 28 .

- The initial investment is calculated by multiplying the amount of each loan, US\$ 6,400, by the total number of families, 75,000, divided by 10 years, which is the construction period: US $\$ 48,000,000$.

- The estimated contribution to be made by each family, US\$ 1,600, is not included in the cash flow because it is not technically cash. As stated previously, this amount represents the value of their own land.

- The families' payments in respect of the amortization of principals and interest are included as an income of the project.

- The annual general and administrative costs relating to the amortized amount have been estimated at $5 \%$.
- A residual value of $10 \%$ (US\$ 4,800,000) is included from year 10 to 19 .

- The economic life of each group of houses is estimated to be 20 years.

Annex 2 presents the financial evaluation according to the parameters set out above. The results are summarized in table 4. Figures 2 and 3 present the sensitivity and risk analysis, respectively.

TABLE 4

\section{Results of the financial evaluation}

\begin{tabular}{lc}
\hline Discount rate & $5.5 \%$ \\
Net present value (NPV) & US\$ 52847178 \\
Internal rate of return (IRR) & $7.25 \%$
\end{tabular}

Source: Prepared by the authors, on the basis of the data in annex 2 .

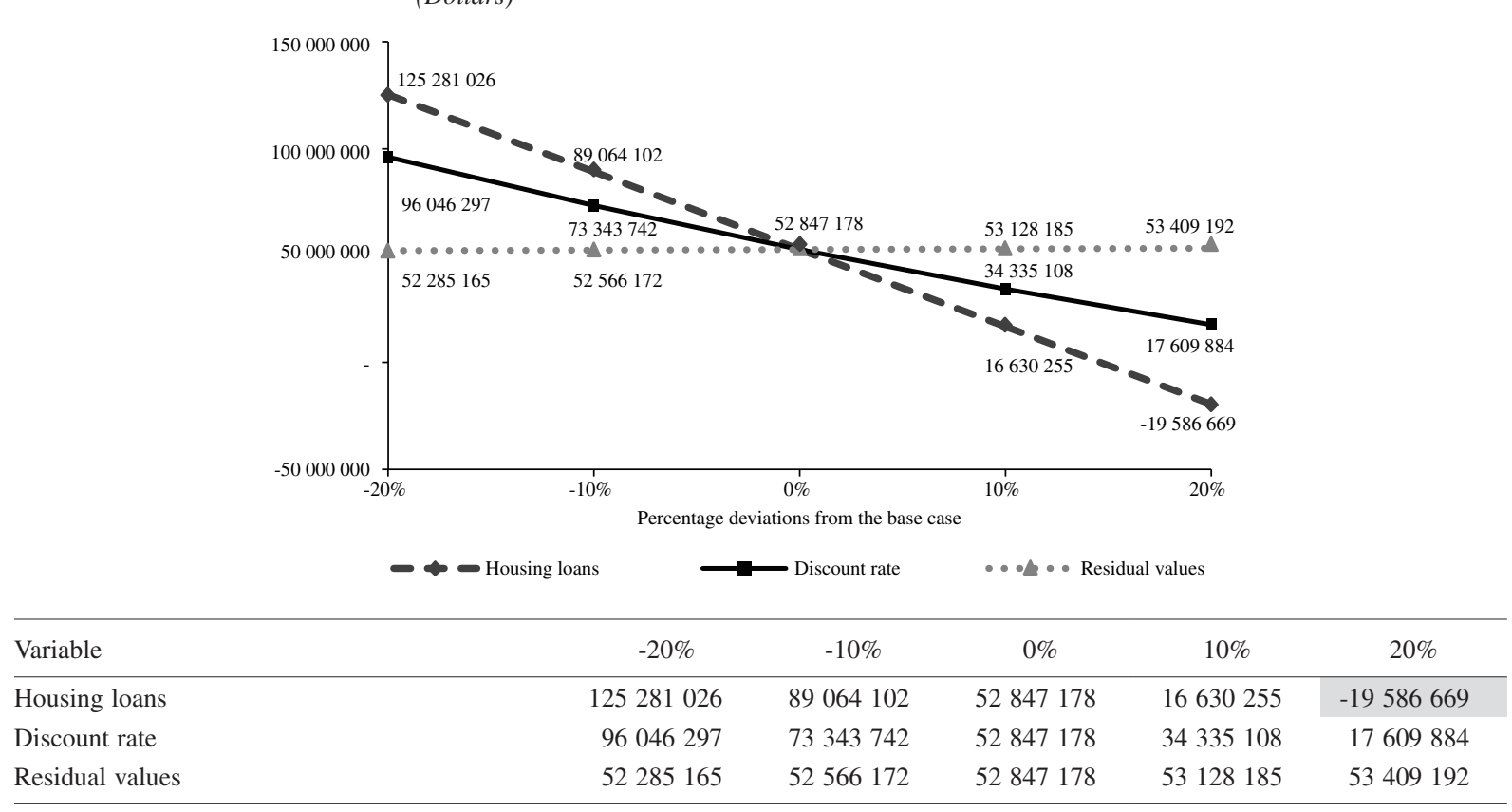

Source: Prepared by the authors, on the basis of the data in annex 2 . 
FIGURE 3

\section{Risk analysis}

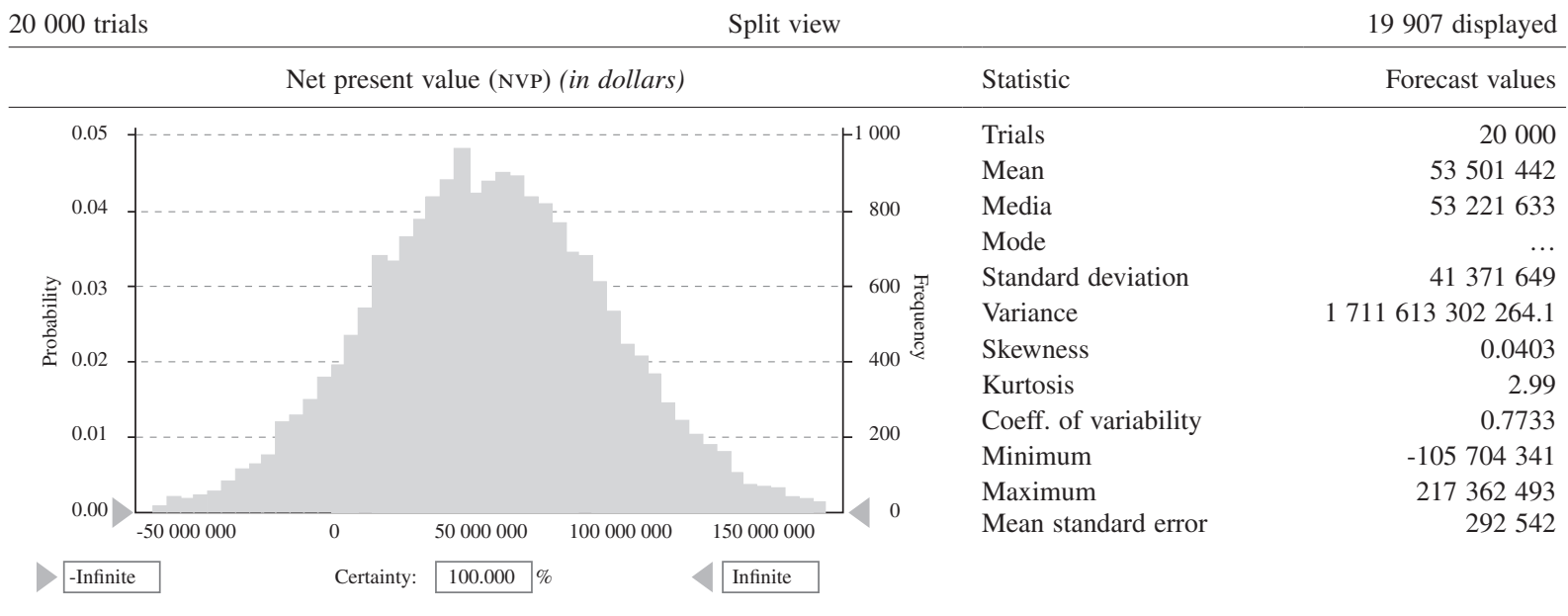

Source: Prepared by the authors.

\section{(e) Comments regarding cash flow}

$\mathrm{AFD}$, as the entity financing the project, will apply the cost of financing at the discount rate, $5.5 \%$. As shown in table 4, the NPV of the project is US\$ $52,847,178$, meaning the investment is viable. The NPV is now even more important, because this is a social project that will not represent a cost to the public finances of Paraguay. Furthermore, if the project were evaluated from the perspective of the economy as a whole, other income and expenditure would need to be included using "shadow prices" and a social discount rate would need to be applied. ${ }^{5}$ All these aspects would further improve the NPV.

Crystal Ball software was used to analyse sensitivity and risk. Three critical variables were selected: the housing loans in the first year, the residual value of the eleventh year, and the discount rate. Figure 2 (sensitivity analysis) shows that the most sensitive variable is the loans to be granted; the second is the discount rate, and the third, the residual value. Figure 3 (risk analysis) presents the results of 20,000 simulations. The main results are: (i) mean NPV, US $\$ 53,501,442$; (ii) standard deviation (risk itself), US\$ 41,371,649; (iii) coefficient of variability (standard deviation/mean NPV), $77.33 \%$; (iv) minimum value, US\$ -105,704,341; and (v) maximum value, US\$217,362,493. All the results of the risk analysis strongly support our evaluation of the project. In this regard, based on the assumptions of normal probability distribution, there is a $68 \%$ probability that the NPV

5 The selection of a discount rate to be applied in the cost-benefit analysis of a social project is one of the more controversial aspects of this area of economics. will range from US\$ 12,129,793 (US\$ 53,501,442 less US\$ $41,371,649$ ) to US\$ $94,873,091$ (US\$ 53,501,442 plus US\$41,371,649).

\section{Long-term bond issue by AFD}

(a) How can the first 10 years of negative flows be financed?

This is the main question that remains unanswered, as we can see in table 5 that the results of the flows are negative during the first 10 years.

Article 1 of Act 2640, through which the Development Finance Agency (AFD) was created, states that AFD can issue bonds in domestic or foreign currency, guaranteed by the State, and authorized by the National Congress in each case, in order to obtain more funds. Paragraph (g) of article 5 adds that AFD funds may be used for the development of housing and urban programmes, and other measures aimed at reducing the housing deficit, and furthermore, that AFD must provide funds to finance housing programmes and individual houses. According to article 98 of Act 4848/13, through which the general budget for 2013 was adopted, AFD is authorized to issue and maintain in circulation registered and tradable bonds worth up to 400 billion guaraníes (approximately US\$ 90 million).

In spite of the immaturity of the Paraguayan stock market, the possibility offered under the law can be used in three different dimensions, so that: (i) AFD acquires the necessary funds to cover the difference in the flows for the first 10 years; (ii) the consecutive issues stimulate the Paraguayan stock market, facilitating the democratization of capital in the country; and (iii) the country's analysts 
TABLE 5

Negative flows during the first 10 years

(Dollars)

\begin{tabular}{ccccccccccc}
\hline \multicolumn{10}{c}{ Years } \\
\hline 2015 & 2016 & 2017 & 2018 & 2019 & 2020 & 2021 & 2022 & 2023 & 2024 \\
\hline-45228000 & -42456000 & -39684000 & -36912000 & -31140000 & -25541250 & -20115750 & -14863500 & -9784500 & -4878750
\end{tabular}

Source: Prepared by the authors.

and potential investment advisers realize that the stock market is becoming more active. As mentioned later, this legislation also offers an excellent opportunity to the stock markets in MERCOSUR countries, which could take part in the transaction and thus turn rhetoric about regional solidarity into action.

(b) The current status of social housing financing As mentioned in the Introduction, Paraguay has no formal housing policy. Some specific, small-scale social housing programmes have been run by the government and by non-governmental organizations; this paper, however, examines how the government has financed the isolated social housing programmes implemented in Paraguay over the past few decades. Financing has come mainly from external and internal sources, managed by the former National Housing Council (CONAVI)/Banco Nacional de Ahorro y Préstamo para la Vivienda (BNAPV) and supervised by another central government entity. CONAVI/BNAPV channelled the funds through commercial banks and eligible savings and loan associations (s\&L), which were in charge of managing the credit operations with the beneficiaries. In the great majority of cases loans were granted at subsidized rates, but regrettably, most went to upper-middle income groups. This situation is illustrated in figure 4.

Non-governmental organizations occupy a prominent place in this figure because they played a key role in the country's housing sector in the 1980s. It may be deduced that the operative structure and the continuity of these programmes were held by public finances. Paradoxically, however, the role of BNAPV related only to control over the savings and loan associations, which were only a small component of Paraguay's financial system. The official institution supervising the participating banks was the Superintendence of Banks.

This financing scheme was unsuccessful because it did nothing to remedy the severe housing shortage. As this paper has shown, there is an urgent housing deficit of 450,000 homes, which directly affects 1.8 million people, or $27.3 \%$ of the population. Our paper presents a feasible financial proposal to address this critical situation.

FIGURE 4

Overview of social housing financing, 1970-2000

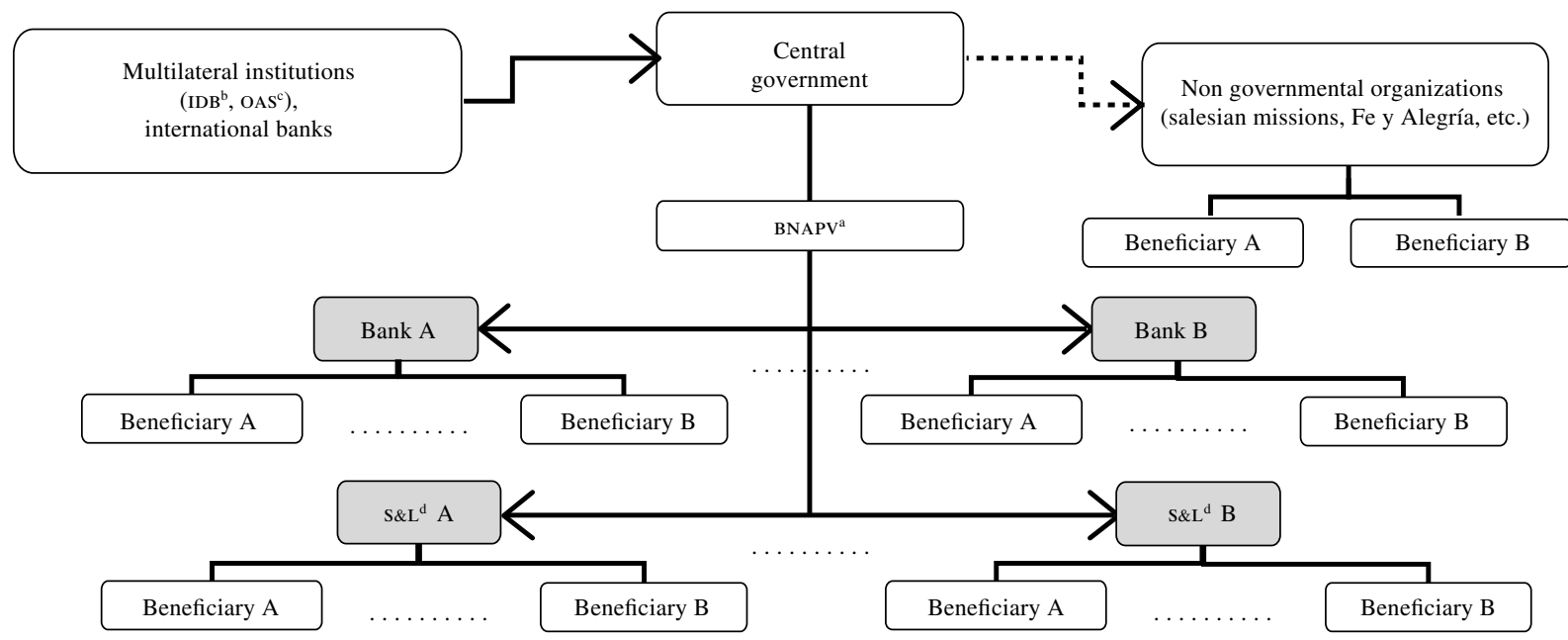

Source: Prepared by the authors.

a Banco Nacional de Ahorro y Préstamo para la Vivienda.

b Inter-American Development Bank.

c Organization of American States. 


\section{(c) Bond issuing proposal for social housing}

Our proposal concerns a financial engineering transaction in which both public and private sector institutions would participate. It consists of a bond issue by AFD, backed by the mortgage loans granted by the intermediary financial institutions to the beneficiaries. These institutions - acting as first-tier financial entitiescharge these loans to AFD, which plays the role of secondtier entity. The stages of the process and the participating organizations are set out below. AFD thus acquires a strategic role and is at the heart of the proposal.

\section{(d) Stages of the process and participating organizations}

Our financing model brings together the public sector (AFD, supported by the central government, the Ministry of Finance, the Central Bank of Paraguay and the National Securities Commission) and the private sector (11 loan cooperatives and one savings and loans association (S\&L), as first-tier organizations, and the Asunción Stock Exchange (BVPASA), commercial banks and other financial institutions as traders of issued bonds). The steps and the organizations involved are as follows:

(i) The beneficiaries negotiate and sign up to a mortgage with a cooperative or S\&L. In addition to all the other legal requirements, the contract must include beneficiaries' obligations.

(ii) The cooperatives and the $S_{L} \&_{L}$ bring together the formalized mortgages and sell them to AFD, but retain the service rights on the mortgages.

(iii) AFD buys them and, pursuant to the law governing its creation, it negotiates with the central government regarding two main issues: authorization to issue new securities on the stock market backed by the respective groups of mortgages; and a government guarantee (issued by the central bank or the Ministry of Finance) covering the issue of these securities. In stock exchange terms, this is known as securitization and is regulated by Act 1036/97 (Securitization Companies Act). In order to maintain the name AFD uses in its financial statements for this type of social housing (viviendas económicas de interés social, veIs), we will refer to these securities as "VEIS bonds."

(iv) Once the relevant approvals have been obtained from the central government relating to the release on the stock market and the guarantee, AFD negotiates with the National Securities Commission, which reports to the Ministry of Industry and Trade, and the Asunción Stock Exchange (BVPASA) regarding the first bonds to be issued in the primary market. (v) Following an analysis, the National Securities Commission authorizes BVPASA as the first issuer in the secondary market.

(vi) The bonds are acquired by commercial banks, the Central Bank of Paraguay, ${ }^{6}$ the National Development Bank, insurance companies and general investors.

(vii) The funds raised in the stock market through the sale of VEIs bonds are transferred to AFD. Simultaneously, AFD transfers them to the cooperatives and the S\&L in payment of the mortgages sold.

(viii) These entities transfer the funds to the accounts of the borrower families, who pay the building companies.

(ix) Later, at each maturity, the beneficiaries pay their mortgages to the cooperatives and the S\&L. These entities transfer the funds to AFD to settle their debt. For obvious reasons, we have not gone into further detail regarding the dealings between the different institutions and financial engineering matters.

(e) Characteristics of the first VEIS bond issue in 2015 Table 6 presents the estimated characteristics of the first bond issue.

All the general characteristics reflect recent issues of treasury bonds on the Asunción Stock Exchange. For example, the interest rate for the last 10-year treasury bonds issued in January 2013 for US\$ 500 million was $4.625 \%$. Therefore, the interest rate of $5 \%$ we have proposed for our bond issues is appropriate. Likewise, the tax percentage is in accordance with fiscal legislation (Ministry of Finance, 2013).

General data on the first veIs bond issue:

- Net AFD income at the time of the issue: US\$44,323,440

- Quarterly interest: US\$ 565,350

- Total principal repayment at the time of redemption: US\$ 45,228,000

- $\quad$ Each year, a fiscal saving of $35 \%$ will be generated on the previous year's interest. A payment of US\$ 791,400 will be made to the Ministry of Finance every June from 2017 to 2026.

- The issue costs will generate, during the following year, a fiscal saving of US\$ 31,660.

Table 7 shows that the annual cost of issuing the bond is $4.16 \%$, while the annual gross and net yields for investors are $5.09 \%$ and $3.8 \%$, respectively.

\footnotetext{
${ }^{6}$ Pursuant to article 16 of Act $42 / 89$, the Central Bank of Paraguay shall acquire veIs bonds from Banco Nacional de Ahorro y Préstamo para la Vivienda (BNAPV) worth up to the equivalent of $5 \%$ of the savings deposited in savings and loan associations.
} 
TABLE 6

Amount of the first VEIS bond issue: US\$ 45,228,000

$\begin{array}{ll}\text { Nominal value of the VEIS bonds } & \text { US\$ } 1000 \\ \text { Number of bonds issued } & 45228 \\ \text { Type of issue } & \text { Par value } \\ \text { Term of subscription } & 20 \text { days before 31 December 2015 } \\ \text { Interest rate } & 5 \% \\ \text { Payment modality } & \text { Quarterly (March 31, June 30, September 30 and December 30) } \\ \text { Subannual periods } & 4 \\ \text { Date of amortization } & \text { Total bonds on 31 December 2025 } \\ \text { Number of quarters } & 40 \text { quarters } \\ \text { Number of years } & 10 \text { years } \\ \text { Amortization price } & \text { Par value }=0 \% \\ \text { Fiscal retention } & 25 \% \\ \text { Administrative costs rate } & 2 \% \\ \text { Income tax rate } & 35 \%\end{array}$

Source: Prepared by the authors.

TABLE 7

Cash flow results for VEIS bond issue 2015

Quarterly cost of bond for AFD

Annual cost of bond for AFD

Quarterly profitability for investors (gross and net)

Annual profitability for investors (gross and net)

Source: Prepared by the authors.

(f) Global balance of the project for AFD

In general terms, the bond issue in the first year -US\$ 45,228,000 — would represent an increase of $11.8 \%$ in total AFD assets in 2013, and an increase of $42.7 \%$ in its bonds and notes liabilities. On 31 December 2013, total AFD assets amounted to US\$ 384.1 million and bond liabilities stood at US\$ 106.0 million. The financial impact of the project on the institution would therefore be significant. The structure of the total project spreads is presented in table 8 .
The spread for AFD among its new liabilities (bonds) and assets (loans to financial institutions), would be $3.73 \%$. That is, the effective interest rate for loans, $7.25 \%$, less the effective cost of bond issues, $3.52 \%$.

The spread for the intermediary financial institutions, meanwhile, would be $4.44 \%$, which is the difference between the effective interest rate for the mortgages, $11.69 \%$, and the effective cost of financing, $7.25 \%$. All of these can be considered an adequate margin for a State-owned bank and cooperatives participating in a social housing project in Paraguay.

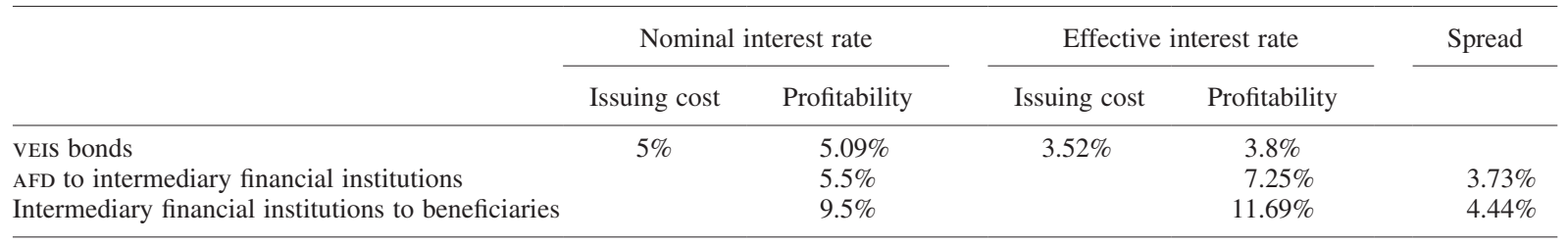

Source: Prepared by the authors. 


\section{(g) Projected situation}

As already stated, the bond issues over the first 10 years will total US\$ 270.6 million. This represents a perfectly tradable amount in Paraguay's financial market. Over the past three years, US\$ 350 million in bonds has been traded on the Asunción Stock Exchange. In addition, between January 2013 and August 2014, the government issued US\$ 1.5 billion, all of which was traded on the international markets.

Figure 5 shows how the market related to the financing of social housing would be structured.

Although the programme would promote and develop alternative sources of financing, it is fair to say that AFD would be exposed to several risks, despite the central government's guarantee, in particular the liquidity, market, and pre-payment risks.

- The liquidity risk refers to the planned bond issues, which will essentially depend on the availability of financial resources in the secondary Paraguayan market.

- The market risk concerns a matter beyond the potential volatility of the long-term investments. Will the Paraguayan stock market be able to absorb the planned annual bond issues? This could be an opportunity for investors from neighbouring countries to participate, and the solidarity of the Southern Common Market (MERCOSUR) should come into play. It would be a good time to turn rhetoric into action, and for the São Paulo Stock Exchange (BOVESPA) and the Buenos Aires Stock Exchange (MERVAL) to participate actively in the operation. Both are, in fact, already involved in other Latin American bond issues.

- The pre-payment risk relates to the possibility of a cut in the market interest rate, which might encourage borrowers to repay their mortgages early.

FIGURE 5

Markets involved in the financing of social housing

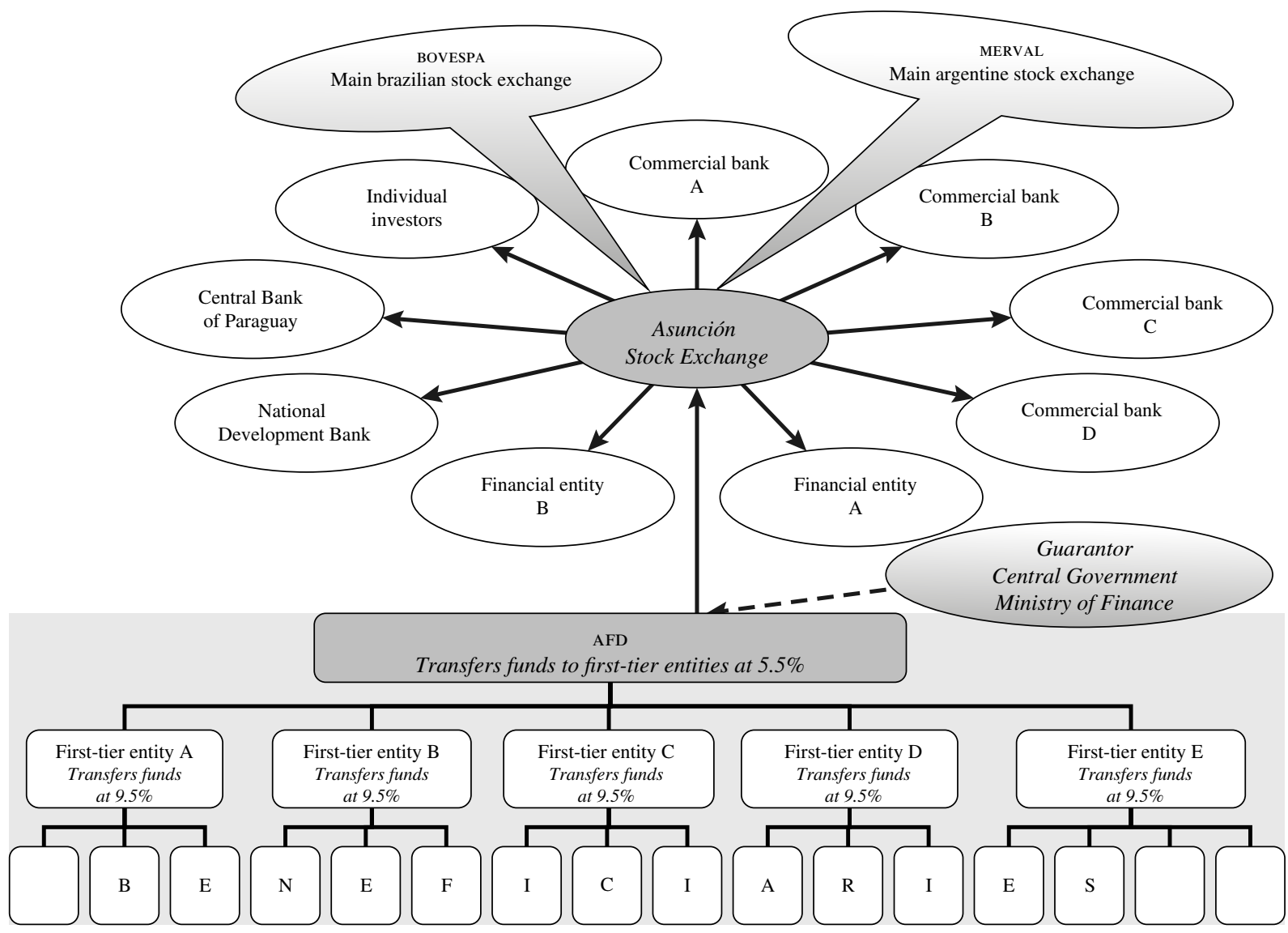

Source: Prepared by the authors. 


\section{V}

\section{Conclusions}

Most Latin American countries have no coordinated housing policies. A few specific activities, managed by development agencies and non-governmental organizations, are undertaken with a small number of beneficiaries. AFD implements some projects, but these are clearly inadequate.

Our proposal is feasible; at US\$ 600 million, or around $2.07 \%$ of Paraguay's gross domestic product (GDP), ${ }^{7}$ the cost of the project does not represent too large a burden for the Paraguayan economy. The necessary funds can be generated if the institutions involved are properly coordinated. However, the Paraguayan government, through AFD, will need to demonstrate commitment and a strong political will. The size of the project could pose some problems for AFD in terms of financial management, but the alarming housing deficit in Paraguay requires decisions of this nature to be taken. Patchwork policies have been implemented for decades.

Around 75,000 middle- to low-income families with limited access to credit in Paraguay's formal financial system could benefit. Under this project, they would be required to pay $16 \%$ of their expected income. The main aim of this proposal is to provide access to a standard home for $4.5 \%$ of the population $(300,000$ people, or

7 According to the World Bank, Paraguay's GDP in 2013 was US\$ 29.01 billion in current terms.
75,000 families with four members). This would also help to stimulate the country's domestic consumption, through the known multiplier effect of construction on the domestic economy. In addition, it would strengthen the financial system, because more households would have a property to offer as collateral in order to secure further loans; this would increase the wealth of the population and hence of the nation.

The Paraguayan government, through AFD, would need to put pressure on the market, break the ice, negotiate with stakeholders, issue the first bonds, and show potential investors and the international rating agencies that the project is viable. The market will recognize and approve the project provided the following two conditions are fulfilled: (i) the construction programme makes progress during the first two years, the investors witness this and realize that they are playing an important role in the real economy; and (ii) the quarterly returns are paid on time.

Our proposal for financing social housing is based on academic research and professional experience in development in several Latin American countries. We realize that this proposal - along with the estimations and the test-error calculations we have performed numerous times - is a global theoretical framework. Each of the processes will need to be submitted to the corresponding technical analysis if it is to be translated into real world practice. Nevertheless, we remain convinced of its economic viability. 
ANNEX 1

Amortization table of loans for families

(Dollars)

\begin{tabular}{|c|c|c|c|c|c|c|c|c|c|}
\hline \multirow{2}{*}{ Years } & \multicolumn{3}{|c|}{ Principal } & \multicolumn{2}{|c|}{ Interest } & \multicolumn{2}{|c|}{$\begin{array}{c}\text { General and } \\
\text { adminstrative costs }\end{array}$} & \multicolumn{2}{|c|}{ Total for each family } \\
\hline & Share & Cumulative & Balance & Annual & Cumulative & Annual & Cumulative & Payment & Cumulative \\
\hline 1 & & 0.0 & 6400.0 & 608.0 & 608.0 & 30.4 & 30.4 & 638.4 & 638.4 \\
\hline 2 & & 0.0 & 6400.0 & 608.0 & 1216.0 & 30.4 & 60.8 & 638.4 & 1276.8 \\
\hline 3 & & 0.0 & 6400.0 & 608.0 & 1824.0 & 30.4 & 91.2 & 638.4 & 1915.2 \\
\hline 4 & & 0.0 & 6400.0 & 608.0 & 2432.0 & 30.4 & 121.6 & 638.4 & 2553.6 \\
\hline 5 & 400.0 & 400.0 & 6000.0 & 570.0 & 3002.0 & 28.5 & 150.1 & 998.5 & 3552.1 \\
\hline 6 & 400.0 & 800.0 & 5600.0 & 532.0 & 3534.0 & 26.6 & 176.7 & 958.6 & 4510.7 \\
\hline 7 & 400.0 & 1200.0 & 5200.0 & 494.0 & 4028.0 & 24.7 & 201.4 & 918.7 & 5429.4 \\
\hline 8 & 400.0 & 1600.0 & 4800.0 & 456.0 & 4484.0 & 22.8 & 224.2 & 878.8 & 6308.2 \\
\hline 9 & 400.0 & 2000.0 & 4400.0 & 418.0 & 4902.0 & 20.9 & 245.1 & 838.9 & 7147.1 \\
\hline 10 & 400.0 & 2400.0 & 4000.0 & 380.0 & 5282.0 & 19.0 & 264.1 & 799.0 & 7946.1 \\
\hline 11 & 400.0 & 2800.0 & 3600.0 & 342.0 & 5624.0 & 17.1 & 281.2 & 759.1 & 8705.2 \\
\hline 12 & 400.0 & 3200.0 & 3200.0 & 304.0 & 5928.0 & 15.2 & 296.4 & 719.2 & 9424.4 \\
\hline 13 & 400.0 & 3600.0 & 2800.0 & 266.0 & 6194.0 & 13.3 & 309.7 & 679.3 & 10103.7 \\
\hline 14 & 400.0 & 4000.0 & 2400.0 & 228.0 & 6422.0 & 11.4 & 321.1 & 639.4 & 10743.1 \\
\hline 15 & 400.0 & 4400.0 & 2000.0 & 190.0 & 6612.0 & 9.5 & 330.6 & 599.5 & 11342.6 \\
\hline 16 & 400.0 & 4800.0 & 1600.0 & 152.0 & 6764.0 & 7.6 & 338.2 & 559.6 & 11902.2 \\
\hline 17 & 400.0 & 5200.0 & 1200.0 & 114.0 & 6878.0 & 5.7 & 343.9 & 519.7 & 12421.9 \\
\hline 18 & 400.0 & 5600.0 & 800.0 & 76.0 & 6954.0 & 3.8 & 347.7 & 479.8 & 12901.7 \\
\hline 19 & 400.0 & 6000.0 & 400.0 & 38.0 & 6992.0 & 1.9 & 349.6 & 439.9 & 13341.6 \\
\hline \multirow[t]{2}{*}{20} & 400.0 & 6400.0 & 0.0 & 0.0 & 6992.0 & 0.0 & 349.6 & 400.0 & 13741.6 \\
\hline & 6400.0 & & & 6992.0 & & 349.6 & & 13741.6 & \\
\hline
\end{tabular}

Source: Prepared by the authors, on the basis of official data from the Department of Statistics, Surveys and Censuses, the Central Bank of Paraguay and the Development Finance Agency (AFD). 
ANNEX 2

Paraguay: cash flow for social housing project

(Dollars)

\begin{tabular}{|c|c|c|c|c|c|c|c|}
\hline Year & $\begin{array}{l}\text { Total collection } \\
\text { of principal }\end{array}$ & $\begin{array}{c}\text { Total collection } \\
\text { of interest }\end{array}$ & $\begin{array}{c}\text { General and } \\
\text { adminstrative revenue }\end{array}$ & $\begin{array}{l}\text { Residual } \\
\text { values }\end{array}$ & $\begin{array}{l}\text { Total cash } \\
\text { inflows }\end{array}$ & $\begin{array}{l}\text { Total cash } \\
\text { outflows }\end{array}$ & Cash flow \\
\hline 0 & 0 & 2640000 & 132000 & & 2772000 & -48000000 & -45228000 \\
\hline 1 & 0 & 5280000 & 264000 & & 5544000 & -48000000 & -42456000 \\
\hline 2 & 0 & 7920000 & 396000 & & 8316000 & -48000000 & -39684000 \\
\hline 3 & 0 & 10560000 & 528000 & & 11088000 & -48000000 & -36912000 \\
\hline 4 & 3000000 & 13200000 & 660000 & & 16860000 & -48000000 & -31140000 \\
\hline 6 & 9000000 & 17985000 & 899250 & & 27884250 & -48000000 & -20115750 \\
\hline 7 & 12000000 & 20130000 & 1006500 & & 33136500 & -48000000 & -14863500 \\
\hline 8 & 15000000 & 22110000 & 1105500 & & 38215500 & -48000000 & -9784500 \\
\hline 9 & 18000000 & 23925000 & 1196250 & & 43121250 & -48000000 & -4878750 \\
\hline 10 & 21000000 & 22935000 & 1146750 & 4800000 & 49881750 & & 49881750 \\
\hline 11 & 24000000 & 21780000 & 1089000 & 4800000 & 51669000 & & 51669000 \\
\hline 12 & 27000000 & 20460000 & 1023000 & 4800000 & 53283000 & & 53283000 \\
\hline 13 & 30000000 & 18975000 & 948750 & 4800000 & 54723750 & & 54723750 \\
\hline 15 & 30000000 & 15675000 & 783750 & 4800000 & 51258750 & & 51258750 \\
\hline 16 & 30000000 & 14025000 & 701250 & 4800000 & 49526250 & & 49526250 \\
\hline 17 & 30000000 & 12375000 & 618750 & 4800000 & 47793750 & & 47793750 \\
\hline 18 & 30000000 & 10725000 & 536250 & 4800000 & 46061250 & & 46061250 \\
\hline 19 & 30000000 & 9075000 & 453750 & 4800000 & 44328750 & & 44328750 \\
\hline 20 & 27000000 & 7425000 & 371250 & & 34796250 & & 34796250 \\
\hline 21 & 24000000 & 5940000 & 297000 & & 30237000 & & 30237000 \\
\hline 22 & 21000000 & 4620000 & 231000 & & 25851000 & & 25851000 \\
\hline 23 & 18000000 & 3465000 & 173250 & & 21638250 & & 21638250 \\
\hline 24 & 15000000 & 2475000 & 123750 & & 17598750 & & 17598750 \\
\hline 25 & 12000000 & 1650000 & 82500 & & 13732500 & & 13732500 \\
\hline 26 & 9000000 & 990000 & 49500 & & 10039500 & & 10039500 \\
\hline 27 & 6000000 & 495000 & 24750 & & 6519750 & & 6519750 \\
\hline 28 & 3000000 & 165000 & 8250 & & 3173250 & & 3173250 \\
\hline
\end{tabular}

Discount rate

Net present value (NPV)

Internal rate of return (IRR)
$5.50 \%$

US\$ 52847178

$7.25 \%$

Source: Prepared by the authors. 
ANNEX 3

Cash flow of VEIS bond issue 2015

(Dollars)

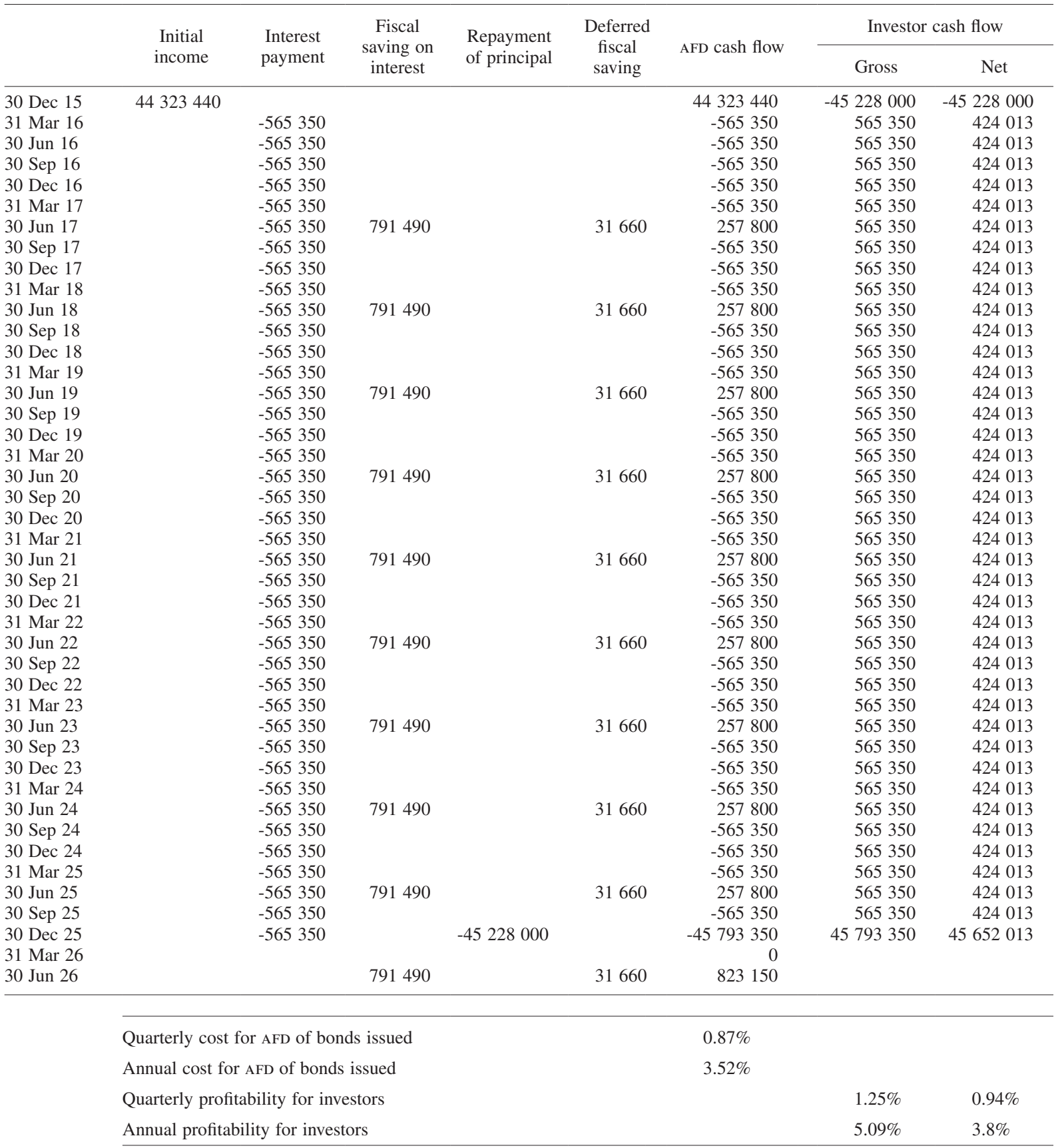

Source: Prepared by the authors. 


\section{Bibliography}

Acemoglu, Daron, Simon Johnson and James A. Robinson (2002), "Reversal of fortune: geography and institutions in the making of the modern world income distribution", The Quarterly Journal of Economics, vol. 117, No. 4, Cambridge, Massachusetts, The MIт Press.

AFD (Development Finance Agency) (2013a), "Llamado a licitación pública para la emisión, negociación, colocación y mantenimiento en circulación de bonos físicos de la agencia financiera de desarrollo, Ley $\mathrm{N}^{\circ} 4.848 / 13$ " [online] http://www.afd.gov.py/ userfiles/file/Emisión\%20Bonos\%20Físicos\%20AFD\%20de\%20 5\%20a\%2010\%20Años\%20(FL181213).pdf.

(2013b), "Estado de la situación patrimonial", 30 June [online] http://www.afd.gov.py /serfiles/file/Balance\%20segundo\%20 trimestre\%202013.pdf.

Bauer, Peter (2000), From Subsistence to Exchange and Other Essays, Princeton, Princeton University Press.

BCP (Central Bank of Paraguay) (2014), "Anexo estadístico del informe económico" [online] https://www.bcp.gov.py/anexo-estadisticodel-informe-economico-i365.

Bouillon, César P. (2012), Un espacio para el desarrollo: los mercados de vivienda en América Latina y el Caribe, Washington, D.C., Inter-American Development Bank.

Coccato, Marcelo (1996), Alternatives to Home Ownership: Rental and Shared Submarkets in Informal Settlements, Montreal, McGill University.

Connolly, Priscilla (1997), "El financiamiento de vivienda en México" [online] http://infonavit.janium.net/janium /UAM/ Documentos/19752.pdf.

Daphnis, Franck (2006), "Microfinanzas para vivienda: hacia una definición”, Microfinanzas para vivienda: una guía para la práctica, Franck Daphnis and Bruce Ferguson (eds.), San Jose, Habitat for Humanity International.

De Leeuw, Frank (1971), "The demand for housing: a review of cross-section evidence", The Review of Economic and Statistics, vol. 53, No. 1, Cambridge, Massachusetts, The MIT Press.

De Soto, Hernando (2000), The Mystery of Capital: Why Capitalism Triumphs in the West and Fails Everywhere Else, New York, Basic Books.

DGEEC (Department of Statistics, Surveys and Censuses) (2012), "Encuesta Permanente de Hogares (EPH)" [online] http://www. dgeec.gov.py/Publicaciones/Biblioteca/EPH2012/principales_ resultados_EPH2012.pdf.

(2011a), "Encuesta Permanente de Hogares (EPH)" [online] http://www.dgeec.gov.py/Publicaciones/Biblioteca/ EPH2011/ Boletin\%20de\%20Pobreza\%20e\%20Ingresos\%202011.pdf.

(2011b), "Principales resultados de pobreza y distribución del ingreso" [online] http://www.dgeec.gov.py/Publicaciones/ Biblioteca/EPH2011/Boletin\%20de\%20Pobreza $\% 20 \mathrm{e} \% 20$ Ingresos\%202011.pdf.

Fallis, George and Lawrence B. Smith (1984), "Uncontrolled prices in a controlled market: the case of rent controls", The American Economic Review, vol. 74, No. 1, Nashville, Tennessee, American Economic Association.

Ferguson, Bruce (2006), "La gran importancia de las microfinanzas para vivienda”, Microfinanzas para vivienda: una guía para la práctica, Franck Daphnis and Bruce Ferguson (eds.), San Jose, Habitat for Humanity International.

Ferguson, Bruce and Jesús Navarrete (2003), "New approaches to progressive housing in Latin America: A key to habitat programs and policy", Habitat International, vol. 27, No. 2.

Ferguson, Bruce and Peer Smets (2010), "Finance for incremental housing; current status and prospects for expansion", Habitat International, vol. 34, No. 3 .
Fonavis (National Social Housing Fund) (2010), Política de aplicación del Fondo Nacional de la Vivienda Social, Asunción, June.

Friedman, Milton (1957), A Theory of the Consumption Function, Princeton, Princeton University Press.

Fruet Cardozo, Juan Vicente (2013), Nuevos modelos alternativos de financiamiento para el Paraguay, Asunción, A.G.R. Servicios Gráficos S.A., November.

González Arrieta, Gerardo M. (2005), "Mortgage loans and access to housing for low-income households in Latin America", CEPAL Review, No. 85 (LC/G.2266-P), Santiago, April.

Hammond, Allen and others (2008), "The next 4 billion - the housing market", Global Urban Development, vol. 4, No. 2 [online] http://www.globalurban.org/GUDMag08Vo14Iss2/Hammond Kramer.htm.

Kerekes, Carrie B. and Claudia R. Williamson (2008), "Unveiling De Soto's mystery: property rights, capital formation, and development", Journal of Institutional Economics, vol. 4, No. 3, Cambridge, Cambridge University Press.

Knapps, Francisco (2013), "Paraguay: déficit habitacional es de 1.200.000 [online] http://ea.com.py/v2/paraguay-deficit-habitacional-esde-1-200-000/.

Lorenz, Max Otto (1905), "Methods of measuring the concentration of wealth", Quarterly Publications of the American Statistical Association, vol. 9, No. 70, Alexandria, American Statistical Association.

Ministry of Finance (2013), "Se realiza hoy la última licitación de bonos del Tesoro en este año", 5 December [online] http:// www.hacienda.gov.py/web-hacienda/index.php?c=96\&n=5576.

Muellbauer, John and Anthony Murphy (1997), "Booms and busts in the UK housing market", The Economic Journal, vol. 107, No. 445 , Wiley.

Muth, Richard F. (1969), Cities and Housing, Chicago, Chicago University Press.

Norton, William A. (1955), Housing Taxation, Madison, University of Wisconsin Press.

Páez, Katherine (2011), "Población, territorio y desarrollo sostenible: notas de la reunión de expertos 16 y 17 de agosto de 2011", Projects Documents (LC/W.438), Santiago, Economic Commission for Latin America and the Caribbean (ECLAC) [online] http:// repositorio.cepal.org/handle/11362/3933.

Poterba, James M. (1984), “Tax subsidies to owner-occupied housing: an asset-market approach", The Quarterly Journal of Economics, vol. 99, No. 4, Oxford University Press, November.

SENAVITAT (National Secretariat for Housing and Habitat) (2012), Déficit habitacional en el Paraguay, Asunción.

(2010), Política de aplicación del Fondo Nacional de la Vivienda Social, Asunción, June.

Serageldin, Mona and John Driscoll (2000), Housing Microfinance Initiatives, Regional Summary: Asia, Latin America and SubSaharan Africa with Selected Case Studies, Center for Urban Development Studies, Harvard University Graduate School of Design, January.

Smets, Peer (2006), "Small is beautiful, but big is often the practice: housing microfinance in discussion", Habitat International, vol. 30, No. 3, Amsterdam, Elsevier.

UNDP (United Nations Development Programme) (2010), UNDP in Action 2010/2011, New York.

Young, Cheryl (2007), "Housing microfinance: designing a product for the rural poor", Working Paper Series, No. 19, Andhra Pradesh, India, Institute for Financial Management and Research, November. 